Núm. 21 - 2019

P. 10-11

\title{
Architecture for Museums
}

\section{Pedro Ignacio Alonso}

Guest Editor

Oslo Architecture Triennale 2016

After Belonging: A Triennale In Residence,

On Residence and the Ways We Stay in

Transit. Comisariada por Lluís Alexandre

Casanovas Blanco, Ignacio González

Galán, Carlos Mínguez Carrasco, Alejandra

Navarrete Llopis, Marina Otero Verzier.

(Fotografía Istvan Virag).

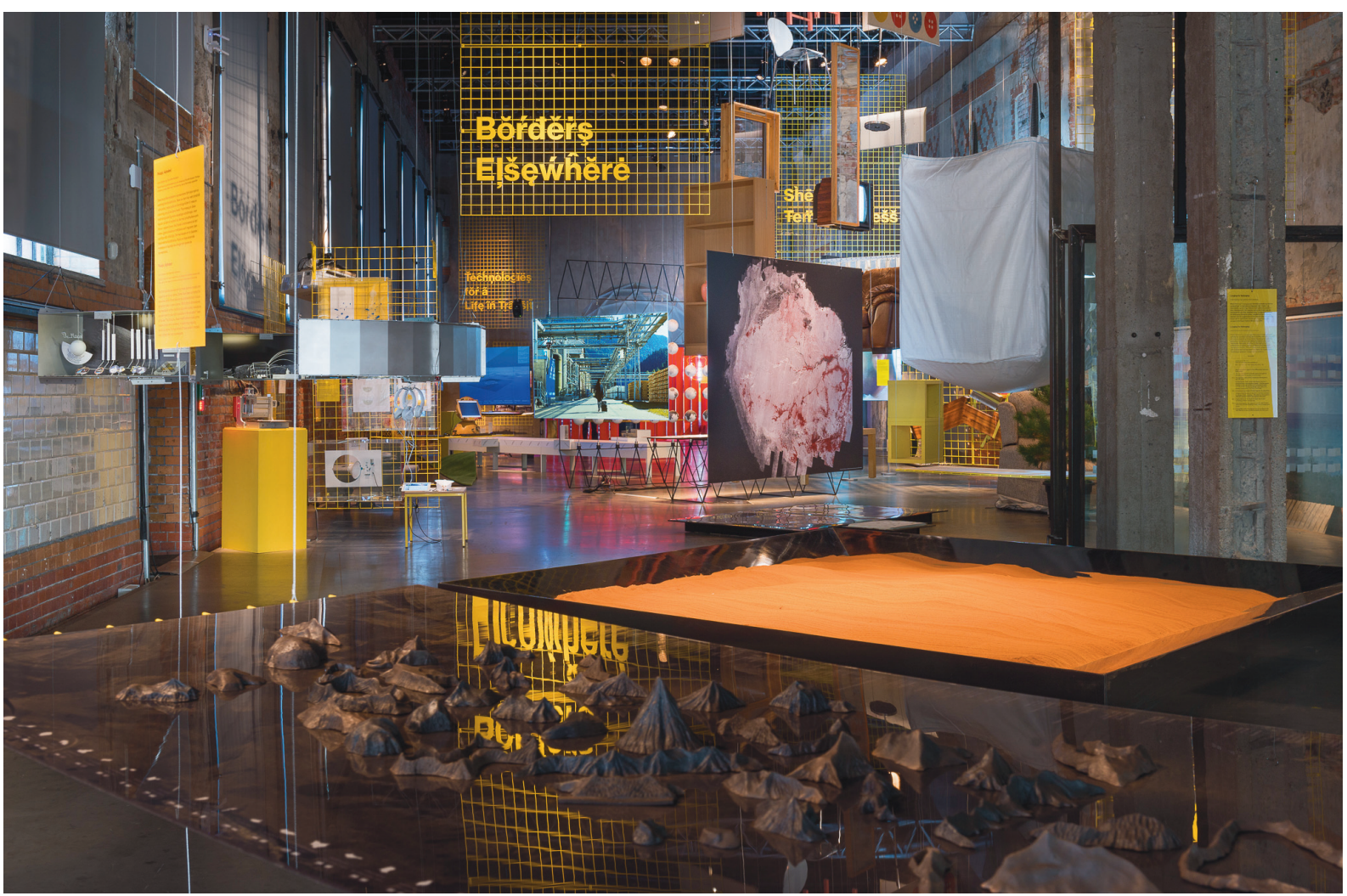


01. ROSSI, Aldo, Arquitectura para los museos (1968), in Para una arquitectura de tendenza: Escritos 1956-1972, Barcelona, Gili, 1977, p. 209. Also see: ROSSI, Aldo, Architettura per i musei, In "Scritti scelti sull'architettura e la città 1956 - 1972", Milano, clup, 1975, p. 337. "E ancora potremmo avere per divisa la celebre frase di Cézanne, "io dipingo solo per i musei". Con questa frase Cézanne, in modo chiarissimo, dichiara la necessità di una pittura che prosegue un suo sviluppo logico rigoroso e che si pone all'interno della logica della pittura che, appunto, viene verificata nei musei [...] L'architettura, nata dalla necessità, è ora autonoma; nella sua forma più elevata essa crea dei pezzi da Museo a cui si rifaranno i tecnici per trasformarli e adattarli alle molteplici funzioni e esigenze a cui devono essere applicati. Cosi dobbiamo educarci sull'analisi dei caratteri costitutivi di un progetto; ed è questo che deve proporsi un corso di teoria della progettazione".

02. Ibid., p. 210.

\section{3. "Mais j'ai voulu faire de}

l'impressionnisme quelque chose de solide et de durable comme l'art des musées" See: GASQUET, Joachim, Cézanne, Paris, Les Éditions Bernheim-Jeune, 1921, p. 90.

04. DORAN, P. M., (ed.). Conversaciones con Cézanne (1978), trans. Pablo Ariel Ires, Buenos Aires, Editorial Cactus, 2016, p. 186

05. “J'ai voulu faire de l'impressionnisme quelque chose de solide et de durable comme l'art des Musées" See: DENIS, Maurice, Théories 1890-1910, Paris, 1913, p. 242.

06. DORAN, P. M., (ed.). Conversaciones con Cézanne (1978), trans. Pablo Ariel Ires, Buenos Aires, Editorial Cactus, 2016, p. 186

07. "Aux deux époques, Cézanne joue le rôle de réactif, il précipite les éléments éphémères, accessoires et de pure sensibilité de l'art moderne et il transforme en harmonieuses et durables formules ceux de ces éléments qui satisfont ses affinités classiques". See: DENIS, Maurice, Théories 1890-1910, Paris, 1913, p. 240.
Fifty years ago, the Italian architect Aldo Rossi spoke of the need to develop an architecture for museums, thereby giving his own spin to the phrase that, according to him, was famously uttered by Paul Cézanne in relation to art: "I paint only for museums". In Rossi's opinion, Cézanne was clearly referring to a type of painting that followed a rigorous development and positioned itself within the logical framework of works whose qualities could be only verified within the space of the museum. In the context of the Italian rationalism of the time, to Rossi, architecture shall be found in its most elevated and autonomous form only in museums. In highly platonic terms, according to his definition, architecture creates museum pieces that only later would be taken up by technicians, to be "transformed and adapted to the multiple functions and needs to which they have to be applied"2.

Given the wealth of consequences for architecture reasoned by Rossi from Cézanne's assertion, it is a pity he doesn't tell us more about the source and context of a statement that seems rather elusive and hard to trace. If not exactly the same, we can find a similar remark in Joachim Gasquet's conversations with the painter, as published in 1921, saying he "wanted to make Impressionism something solid and durable like the art of museums"3. About Gasquet's book, Michael Doran points out that the dialogues combine the authentic with the speculative, presenting -as into a seamless conversation- quotations from letters between Cézanne and Camoin, or else, passages from Bernard's Recueils, and excerpts from a 1907 article on Cézanne by Maurice Denis, later republished in his Théories $1890-1910^{4}$. There, in fact, according to Denis, Cézanne told him, “J'ai voulu faire de l'impressionnisme quelque chose de solide et de durable

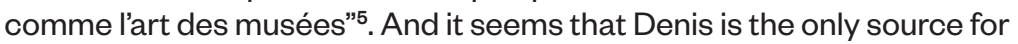
these famous words, that he might have taken from notes ${ }^{6}$. Words, therefore, that were then borrowed by Gasquet in making up his own dialogues, and perhaps, several decades later, were reshaped by Rossi into his own architectural argument.

Rossi's fascination with Cézanne is understandable. Ultimately, this is the painter that having a "pure modern sensibility", would discard "all ephemeral and accessory elements, transforming them into harmonious and durable formulas that would satisfy his classic affinities"7. And his capacity of abstraction went so far as to reduce all forms only to those that he is capable of thinking: the sphere, the cone, and the cylinder ${ }^{8}$. Becoming Rossi's alter ego by choice, Cézanne would connect the intuitive with the rational, "...his eye would discover first what his reason would immediately and spontaneously provide with the logical support of composition, plan, and architecture" "It would be possible to say, therefore, that Rossi aimed the same that Cézanne had done for painting, faire de l'architecture quelque chose de solide et de durable comme l'art des musées, by means of discarding all ephemeral elements, transforming them into durable formulas that would satisfy his classic affinities. 
But the weight of eternity implicit in the solid and the durable was not the only way Cézanne regarded such institutions. At the end of his conversation with Gasquet, he would also say that "Museums are Plato's caves"10. Almost reversing Rossi's frenzy Platonism, Cézanne would think that together with beholding durable formulas, museums are also the reservoir of mere shadows. And he continues: "On their doors I will have engraved: 'Defend the painters from entering. There is sun outside.' [...] After [a painter] returns from these cemeteries, I order him simply to rest and meditate on his helplessness [...] Museums are odious places, they stink democracy and college"11. These assertions do not come from an elderly painter willing to advise younger generations. Quite early in his career, when he was twenty-five years of age, "with admirable health, a warm heart and blood, and an abundance of ideas", one day he cried to Huot: "We must burn the Louvre"12.

Rossi's obvious omissions and deformations provide us with a clear example on the ambivalent status that museums can hold for art and architecture, revealing seemingly opposite understandings that well continue in the contemporary. Of course, museums today are not quite what they were at the end of the nineteenth century when Cézanne was uttering his words. And Rossi's limited idea -by not explicitly acknowledging that museums are not neutral spaces- disregard the fact that at least for architecture, in contemporary fashion, eternity is provided only insofar museums have been transformed into archives. This is true, at least in Rossi's case, as his own collections are kept at The Canadian Centre for Architecture (CCA) in Montreal, an international research institution, archive, library and gallery.

Something remains, however, from Cézanne's debate. Museums and archives, as well as galleries, biennials and triennials are still set to divide what must be inside from what shall remain in the outside. Cézanne's drive to engrave the doors is telling about the thresholds, the points, where both literally and symbolically works of art or architecture could enter a certain realm: the permanent transit, if not the transaction, that moves objects from the external to the internal, and back from the inner to the outer. The strengthening -or the blurring- of these doors and dividing lines thus becomes the locus of many contemporary controversies.

Of course, as presented here, these ideas may look oversimplifying more complex and entangled processes but allow us to discuss historical and contemporary subjects and examples contributing to a critical debate on architectural and curatorial practices that conceive the museums as a working space for exploration, and the place where the architect's work can achieve its highest level of understanding. The aim of the present issue of RA Revista de Arquitectura is both to offer, and to widen, this debate. RA
08. "Toute sa faculté d'abstraction - et l'on voit ici à quel point le peintre l'emporte en lui sur le théoricien - toute sa faculté d'abstraction va jusqu'à ne distinguer de formes notables que "la sphère, le cône et le cylindre". Toutes les formes se ramènent à celles-là seulement qu'il est capable de penser". DENIS, Maurice, Théories 18901910, Paris, 1913, p. 249

09. “...que son œil découvrait d'abord mais que sa raison voulait aussitôt et spontanément appuyer sur le support logique d'une composition, d'un plan, d'une architecture". See: DENIS, Maurice, Théories 1890-1910, Paris, 1913, p. 242.

10. "Les musées sont des cavernes de Platon. Sur la porte je ferai graver: "Défense aux peintres d'entrer. Il y a le soleil dehors". Un peintre commence à peindre, ce qui s'appelle peindre, a quarante ans, un peintre de nos jours. Les autres, a cet âge, lorsqu'il n'y avait pas de musée, avaient presque achevé leur œuvre. Un peintre aujourd'hui ne sait rien. Jusqu'à quarante ans, oui, qu'il fréquente les musées, je le lui ordonne. Après qu'il retourne dans ces cimetières simplement pour s'y reposer et y méditer sur son impuissance et sur sa mort... Les musées sont des lieux odieux. Ils puent la démocratie et le collège". GASQUET, Joachim, Cézanne, Paris, Les Éditions Bernheim-Jeune, 1921, p. 124.

11. "Les musées sont des cavernes de Platon. Sur la porte je ferai graver: "Défense aux peintres d'entrer. Il y a le soleil dehors". Un peintre commence à peindre, ce qui s'appelle peindre, a quarante ans, un peintre de nos jours. Les autres, a cet âge, lorsqu'il n'y avait pas de musée, avaient presque achevé leur œuvre. Un peintre aujourd'hui ne sait rien. Jusqu'à quarante ans, oui, qu'il fréquente les musées, je le lui ordonne. Après qu'il retourne dans ces cimetières simplement pour s'y reposer et y méditer sur son impuissance et sur sa mort...Les musées sont des lieux odieux. Ils puent la démocratie et le collège". GASQUET, Joachim, Cézanne, Paris, Les Éditions Bernheim-Jeune, 1921, p. 124.

12. Ibid., p. 29. 